\title{
Evaluation and Comparison between Physical and Chemical Properties of Two Variety Wheat
}

\author{
Minali Masih $^{1 *}$, Tushar V. Desale ${ }^{2}$ and Shivani Saini ${ }^{3}$ \\ '221/D New Ruabandha Sector, Bhilai (C.G.), India \\ ${ }^{2}$ 43/A, J.B. Badgujar Colony, Deoour, Dhule, M.H., India \\ ${ }^{3}$ Near Galla Godam, Godali Road, Pauri, Garhwal, Uttrakhand, India \\ *Corresponding author
}

\section{A B S T R A C T}

\begin{tabular}{|c|}
\hline Keywords \\
\hline $\begin{array}{l}\text { Wheat, Sharbati } \\
\text { wheat, Lokwan } \\
\text { wheat, Maida, } \\
\text { Semolina }\end{array}$ \\
\hline Article Info \\
\hline $\begin{array}{l}\text { Accepted: } \\
20 \text { June } 2020 \\
\text { Available Online: } \\
10 \text { July } 2020\end{array}$ \\
\hline
\end{tabular}

The present study was aimed to evaluate and compare the physical and chemical properties of the two varieties of wheat which were sharbati variety and lokwan variety and also evaluating and comparing the physical and chemical properties of the flours (maida, chakki atta, mill atta and semolina) obtained from the above two varieties of wheat. The properties tested for the wheat were hectoliter test, dimensional analysis of wheat kernel and the moisture content of the wheat and as for the flours sieve analysis, colour test, moisture content test, ash content test, gluten test and strength of the flour were tested to know about the physical and chemical properties of them. Evaluations were made between the physical and chemical properties which were evaluated by conventional and standard methods and comparisons were made between the two varieties of wheat and the flours obtained from them.

\section{Introduction}

\section{Wheat}

Wheat is one of the world's most important grains, with annual world production of about 600 million tons. Approximately $70 \%$ of wheat is used for food production. In Chhattisgarh, wheat occupies average of 3.6 million ha. with the productivity of the state ranging between 1.2 to $1.6 \mathrm{t} / \mathrm{ha}$ depending upon the rainfall. Wheat is milled into maida, chakkiatta, mill atta and semolina which is then made into products such as bread, cakes, chapatti, macaroni and noodles. The miller has two main aims: first, to supply the customer with the specified product quality and second, to efficiently separate the endosperm from the bran. The flour yield and flour properties, among other things, are strongly related to wheat kernel properties, especially to thephysical properties (Dariusz 
Dziki, Janusz Laskowski, 2005).

\section{Milling of wheat}

Milling is the process by which cereal grains are ground into flour. Traditionally, and in some parts of the world to this day, this would have been accomplished by grinding the grain between two stones, a lower, stationary stone called the quern stone and an upper, mobile stone called the handstone (Mark Winfield). The four predominant techniques for grinding whole grain flours are stone mill (SM), roller mill (RM), ultra-fine mill (UM) and hammer mill (HM) (Kent and Evers, 1994). The hammer mill causes the product to be heated up and to lose moisture (Posner and Hibbs, 2005).Stone mills generate considerable heat due to friction, resulting in damage to starch, protein, and unsaturated fatty acids (Prabhasanka and Rao, 2001). The process of roller milling involves separation of the endosperm from the bran and germ followed by gradual size reduction of endosperm (Ziegler and Greer, 1971).

Physical and chemical properties of wheat and flours are grain size, color, moisture content and ash content. The grain length and grain thickness were significantly affected due to the differences in wheat varieties while grain width did not differ significantly among the wheat varieties. The thickness, width and height are measured with the help of electronic vernier caliper.

The ash content influences the colour of flours. (Hal'aszn'e et al., 1995) proposed a qualification system based on the colour measurements of durum semolina. During the product manufacturing, the colour characteristics were mainly used to determine the appropriate roastedness (Hotti et al., 2000). Determining moisture content is an essential first step in analysing wheat or flour quality since this data is used for other tests. Flour millers adjust the moisture in wheat to a standard level before milling. Moisture content of 14 percent is commonly used as a conversion factor for other tests in which the results are affected by moisture content. Moisture is also an indicator of grain storability. Wheat or flour with high moisture content (greater than 14.5 percent) attracts mold, bacteria and insects, all of which cause deterioration during storage. The flour with moisture content in the range of 13-15\% which is within the range for the effective storage of flour were studied (Whiteley, 1971). Moisture content of $12-15.5 \%$ has been specified for cereal flour storage. Failure to store flour under this conditions leads to moisture absorption from the atmosphere, which eventually leads to caking (Kent 1980).Moisture content of wheat is determined by hot air oven. The minerals in wheat grain are located mainly in its peripheral layers. The flours of high extraction containing the grain envelope part have higher ash content than flour from low extraction by the endosperm which is poorer in mineral substances. The value of ash content, in both wheat and especially in the flour is a basic quality index, differentiating the extraction flour types (Bordei et al., 2007).

In this research study, evaluation and comparison of physical and chemical properties of two varieties are made between sharbati and lokwan variety which are the local wheat varieties of Madhya Pradesh, India.

\section{Materials and Methods}

This chapter deals with the various experiments and techniques used for the study of physical and chemical properties of wheat and the flour made from wheat. The testing was carried out in Grains Processing unit, Mahamara, Durg (C.G.). 


\section{Apparatus used}

In this study, instruments/apparatus will be used for the study and comparisons of wheat and its flours i.e., digital vernier caliper, moisture meter, weighing machine, petri dish, desiccators, wooden scale crucible dish, hot air oven, sieve analysis apparatus, ash furnace, cooling dish, measuring scale, bread mould, mixing bowl, volume container.

\section{Methods and procedure}

\section{Dimensional analysis of wheat}

The length, width and thickness of nine different samples of wheat kernels were measured by using digital vernier caliper. The average of nine values was calculated to get the dimensions of wheat.

\section{Hectolitremass of wheat}

Fill the hopper of hectolitre with sharbati variety of wheat. Close the lid of the hectolitre. Remove the extra wheat by tilting the hectolitre. Now weight the wheat by using the electronic weighing machine. Repeat the above steps for lokwan variety of wheat.

\section{Moisture test of wheat}

Take volume A (fix volume of grain) of wheat and put it in moisture meter. Adjust the pressure of moisture meter to 462 on scale of moisture meter. Switch on the measuring button of moisture meter. After the beep sound the required moisture is displayed on the screen of moisture meter.

\section{Color test}

Take a small amount of flour and set it on wooden scale. Dip it in water for a second or two. Let it dry in room temperature. The color is determined by sensory analysis. The cracks appeared on flour are also seen for quality check of flours.

\section{Moisture test for flours}

Take $10 \mathrm{gms}$ of flour in petridish. Measure the weight of petridish and sample weight together for wet weight. Put the sample in hot air oven for $2 \mathrm{hrs}$ at $130^{\circ} \mathrm{C}$. Cool the sample in desiccator for 15 minutes. Now weight the sample and petridish for dry weight (WD).

Formula Used -

$W w-W d=W$

$\frac{W \times 100}{10}=\mathrm{MC}$

Here,

$\mathrm{W}_{\mathrm{W}}$ - Wet basis weight

$\mathrm{W}_{\mathrm{d}}$ - Dry basis Sweight

MC - Moisture content (\%)

\section{Ash content test}

Take a crucible dish and measure its weight $\left(\mathrm{W}_{1}\right)$. Take about $10 \mathrm{gms}$ sample $\left(\mathrm{W}_{2}\right)$. Put the sample in crucible dish in furnance for about $6 \mathrm{hrs}$ at $600^{\circ} \mathrm{C}$. Cool down the sample in desiccator for 15 minutes. Now weight the sample with crucible dish which will be the dry weight $\left(\mathrm{W}_{3}\right)$ Formula Used-

$\frac{\mathrm{W}_{3}-\mathrm{W}_{1}}{100-\mathrm{MC}} \times 10000=\mathrm{A}$

$\frac{\mathrm{A}}{\mathrm{W}_{2}}=\mathrm{AC} \%$

Here,

$\mathrm{W}_{1}$ - Weight of crucible dish

$\mathrm{W}_{2}$ - Weight of sample

$\mathrm{W}_{3}$ - Weight of crucible dish and sample after drying

AC - Ash content (\%) 


\section{Gluten test}

Take $25 \mathrm{gm}$ of sample flour. Add about $15 \mathrm{ml}$ of water and make it into dough and give it a spherical shape. Dip the dough in water for about $1 \mathrm{hr}$. After $1 \mathrm{hr}$ take out the dough and wash it with water. Dry it in room temperature for removing the extra water. Now weight it which will be the wet weight.

Formula used for wet basis

$$
\mathrm{G}_{\mathrm{w}} \%=\frac{\mathrm{W}_{\mathrm{W}} \times 4}{3}
$$

i. Put it in oven for $2.5 \mathrm{hrs}$ at $170^{\circ} \mathrm{C}$ on a paper.

ii. Now weight the sample to get the dry weight $\left(\mathrm{W}_{\mathrm{D}}\right)$ also weight the paper $\left(\mathrm{W}_{\mathrm{P}}\right)$.

iii. Multiply the dry weight with 4 to get the values for $100 \mathrm{gms}$ of sample.

Formula Used -

$\frac{W_{D}-W_{p}}{100-M C} \times 10000=B$

$\frac{\mathrm{B}}{25}=\mathrm{G}_{\mathrm{D}} \%$

Here,

$\mathrm{W}_{\mathrm{W}}$-Wet basis weight

$\mathrm{W}_{\mathrm{D}}$ - Dry basis weight

$\mathrm{W}_{\mathrm{P}}$ - Paper weight

$\mathrm{G}_{\mathrm{W}^{-}}$Gluten content on wet basis (\%)

$\mathrm{G}_{\mathrm{D}}$ - Gluten content on dry basis (\%)

\section{Water absorption power}

The amount of water required to make the dough for gluten is multiplied by 4 to get the water absorption power of flour for 100 gms. Expressed in terms of percentage $(\%)$. Water absorption power must be minimum $60 \%$ for an ideal flour.

\section{Sieve analysis testing for purity}

100 gms sample of flour is taken in uppermost sieve (sieve size as per the flour) of sieve analysis apparatus. $132 \mu$ sieve size is kept below and is used for every flour. Set the timer for $5 \mathrm{~min}$. After sieving the retained impurity is weighted.

\section{Strength of maida}

Take 300 gms sample of maida. Add 2\% yeast, $4 \%$ sugar, $1 \%$ salt, $150 \mathrm{ml}$ water, 3-4 gms oil. Mix the above ingredient and stand it for about 30 minutes. After 30 minutes quill the dough for 5 minutes. Coat the bread mould with oil. Put the dough in the mould and cover it with wet cloth. Rest it for about 1 hr. Now bake it in oven for 20-25 minutes at $250^{\circ} \mathrm{C}$. Measure the rise with the measuring scale.

\section{Results and Discussion}

\section{Physical and chemical properties of wheat}

\section{Dimensions of wheat}

The length, width and thickness of three different samples of wheat kernels were measured by using digital vernier caliper. The length is measured from top to bottom of wheat kernel. The width is measured from the side to side portion of wheat kernel. The thickness is measured from the cut side and the side opposite to it. Table 1 shows the result after the measuring the dimensions from digital vernier caliper.

The length of sharbati wheat when measured by digital vernier caliper was found to be $6.055 \mathrm{~mm}$, the breadth was $3.433 \mathrm{~mm}$ and thickness was $2.733 \mathrm{~mm}$. It is almost the usual size of wheat which are popular these days. The length of lokwan wheat was to be $7.1 \mathrm{~mm}$, breadth was found to be $3.411 \mathrm{~mm}$ 
and thickness was $2.766 \mathrm{~mm}$ which is bigger in size as compared to the sharbati variety wheat.

\section{Hectolitre test}

Hectolitre mass, is a measure of the volume of grain per unit. It is usually expressed as kilograms per hectolitre and is a good indication of grain-soundness. Millers usually use test weight as an indication of expected flour yield. The factors affecting the hectolitre weight are kernel shape and uniformity of kernel size, orientation of kernels in container when it is filled, density of the grain influenced by structure of grain and its chemical composition. The results obtained from this test are shown in table 2.

The hectolitre mass of sharbati variety wheat was found to be $82 \mathrm{~kg} / \mathrm{hl}$ and the hectolitre mass for lokwan variety was found to be 78 $\mathrm{kg} / \mathrm{hl}$. The difference in hectolitre mass occurred due to the density of grain the and also the kernel size as lokwan variety wheat was a bit bigger in size as compared to the sharbati variety. The uniformity in kernel size was observed in both the samples of the two varieties thus the difference in hectolitre mass was not influenced by it.

\section{Moisture content of wheat}

The moisture of wheat is measured by two methods. Moisture meter and AACC International Approved Methods of Analysis of Moisture Air-Oven Method were used. There was a very difference in the moisture content obtained from the themethids but both are reliable for testing the moisture content of wheat. The result of the are shown in tabular form in Table 3.

The moisture content of wheat must range from $12 \%$ to $16 \%$. The moisture content measured from moisture meter of sharbati variety shows the moisture of about $15.61 \%$ while moisture obtained from air oven method is about $15.276 \%$ of same wheat variety. The moisture content measured from moisture meter of lokwan variety shows the moisture of about $14.108 \%$ while moisture obtained from air oven method is about $14.821 \%$ of same wheat variety. The moisture obtained for lokwan variety wheat was less as compared to the sharbati variety wheat.

\section{Physical and chemical properties of flours obtained from the two varieties}

\section{Sieve analysis for purity}

The sieving is done as per the standard sieve sizes used for various flours obtained from the two varieties of wheat. The retained flours are given in grams as per the various sieve sizes. The results were shown in tabular form in Table 4.

\section{Sharbati variety}

From above table we can see that for sieve size of $150 \mu, 0.052 \mathrm{gms}$ of flour is retained and for $132 \mu, 1.398$ gms of flour is retained for maida I. For sieve size of $180 \mu, 0.196 \mathrm{gms}$ of flour is retained and for $132 \mu, 2.156 \mathrm{gms}$ of flour is retained for maida II.

For sieve size of $212 \mu, 5.489 \mathrm{gms}$ of flour is retained and for $132 \mu, 10.736$ gmsof flour is retained for chakkiatta. For sieve size of $212 \mu, 9.7$ gms of flour is retained and for $132 \mu, 60.472$ gms of flour is retained for mill atta.

\section{Lokwan variety}

For sieve size of $150 \mu, 0.079 \mathrm{gms}$ of flour is retained and for $132 \mu, 1.982 \mathrm{gms}$ of flour is retained for maida I. For sieve size of $180 \mu$, $0.250 \mathrm{gms}$ of flour is retained and for $132 \mu$, 
$2.413 \mathrm{gms}$ of flour is retained for maida II. For sieve size of $212 \mu, 5.025 \mathrm{gms}$ of flour is retained and for $132 \mu, 12.371 \mathrm{gms}$ of flour is retained for chakki atta.

For sieve size of $212 \mu, 10.246$ gms of flour is retained and for $132 \mu, 62.002$ gms of flour is retained for mill atta.

By adding the above two weight obtained from the two sieve sizes for each flour we get the impurity for that specific flour. The purity of the flours is determined by subtracting the impurity from 100 . This will give the purity of flour in percentage. Minimum purity for maida I and maida II must be $95 \%$, for chakki atta must range from $55 \%$ to $62 \%$ and for mill atta must range from $25 \%$ to $35 \%$. The results are shown in Table 5.

\section{Sharbati variety}

The purity of maida I was found to be $98.55 \%$, for maida II was $97.64 \%$, for chakki atta was found to be $98.767 \%$.

\section{Lokwan variety}

The purity of maida I was found to be $97.939 \%$, for maida II was $97.337 \%$, for chakki atta was $65.208 \%$ and mill atta was found to be $27.752 \%$.

The impurity of flour is due to the presence of bran and germ. The percentage of of bran and germ in sharbati variety was less as compared to lokwan variety. Due to this reason the impurity percentage in lokwan variety maida I, maida II, chakki and mill atta was found to be more than sharbati variety.

\section{Colour testing of flours}

The colour of the flours obtained varies as per the varieties of wheat. The two varieties shows difference in color obtained from the color testing of the flours. It is basically a sensory test which was compared by using a pre defined scale. Table 6 shows the results obtained from the flours of sharbati and lokwan variety.

From the table we can compare the colour of the two varieties of wheat that the maida from sharbati variety gives a brighter and lighter colour as compared to the lokwan variety maida. There was no difference in the colour in the chakki atta, mill atta and semolina of the two varieties of the wheat. The bran and germ in lokwanwas in high percentage giving the flours obtained from it a dull colour as compared to sharbati variety flours. Since bran and germ are included in the atta and semolina there was no difference in their colour and variation was observed only in the maida obtained from the two varieties.

\section{Moisture content of flours}

The moisture of wheat is measured by AACC International Approved Methods of Analysis of Moisture Air-Oven Method. The results are shown in tabular form in Table 7.

From above table we found that the moisture content obtained for sharbati maida I is $13.724 \%$, for maida II is $13.129 \%$, for chakki atta is $11.077 \%$, for mill atta is $14.38 \%$ for semolina $\mathrm{I}$ is $13.88 \%$ and for semolina II is $14.38 \%$.

The moisture content obtained for lokwan maida I is $12.010 \%$, for maida II is $12.448 \%$, for chakki atta is $10.532 \%$, for mill atta is $12.731 \%$, for semolina $\mathrm{I}$ is $12.961 \%$, and for semolina II is $13.6599 \%$.

The moisture content of sharbati wheat was more than lokwan wheat the moisture content of their respected flours was more for sharbati variety as compared to that of lokwan variety. 


\section{Ash content}

The moisture of wheat is measured by AACC International Approved Methods of Analysis of Ash-Basic method. The AACCI Method is based on the fact that when a sample is incinerated in an oven, the high temperature vaporizes the moisture and burns away all the organic materials (starch, proteins, sugars, and fat), leaving only the ash. The residue is composed of the non-combustible, inorganic minerals that are concentrated in the bran layer.The results are shown in tabular form in Table 8.

According to the Food Safety and Standards Authority of India (FSSAI) the allowable ash content for maida I, maida II and mill atta is maximum $1 \%$ while for chakkiatta is $5 \%$ at most.
From above table we can see that the ash content in sharbati variety obtained for maida I is $0.509 \%$, for maida II is $0.815 \%$, for chakkiatta is $1.43 \%$ and for mill atta is $0.565 \%$. The ash content in lokwan variety obtained for maida I is $0.719 \%$, for maida II is $0.922 \%$, for chakkiatta is $1.669 \%$ and for mill atta is $0.846 \%$.

\section{Gluten content}

Gluten is measured on wet basis and dry basis. Hot air oven is used for measurement of gluten. Separate tables show the result for the gluten percentage in wet basis (Table 8) and in dry basis (Table 9).

Minimum gluten content for good quality flour on wet basis must be minimum $6 \%$ and as for dry basis it must be minimum $7.5 \%$.

Table.1 Average dimensions of the two variety of wheat

\begin{tabular}{|c|c|c|c|}
\hline Variety & Length $(\mathbf{m m})$ & Breadth $(\mathbf{m m})$ & Thickness $\mathbf{( m m )}$ \\
\hline Sharbati & 6.055 & 3.433 & 2.733 \\
\hline Lokwan & 7.1 & 3.411 & 2.766 \\
\hline
\end{tabular}

Table.2 Result obtained from the hectolitre test.

\begin{tabular}{|c|c|c|c|}
\hline Variety & Volume (ltr) & Mass (kg) & Hectolitre Mass (kg/hl) \\
\hline Sharbati & 0.5 & 0.410 & 82 \\
\hline Lokwan & 0.5 & 0.390 & 78 \\
\hline
\end{tabular}

Table.3 Moisture content of wheat in percentage (\%)

\begin{tabular}{|c|c|c|}
\hline Variety & Moisture Meter (\%) & Air Oven Method (\%) \\
\hline Sharbati & 15.19 & 15.28 \\
\hline Lokwan & 14.11 & 14.82 \\
\hline
\end{tabular}

Table.4 Retained flour on various sieve sizes in grams

\begin{tabular}{|c|c|c|c|c|c|c|c|c|}
\hline \multirow{2}{*}{ Variety } & \multicolumn{2}{|c|}{ Maida I } & \multicolumn{2}{c|}{ Maida Ii } & \multicolumn{2}{c|}{ Chakki Atta } & \multicolumn{2}{c|}{ Mill Atta } \\
\cline { 2 - 9 } & $\mathbf{1 5 0} \boldsymbol{\mathbf { 1 3 2 }}$ & $\mathbf{1 8 0} \boldsymbol{\mu}$ & $\mathbf{1 3 2} \boldsymbol{\mu}$ & $\mathbf{2 1 2} \boldsymbol{\mu}$ & $\mathbf{1 3 2} \boldsymbol{\mu}$ & $\mathbf{2 1 2} \boldsymbol{\mu}$ & $\mathbf{1 3 2} \boldsymbol{\mu}$ \\
\hline Sharbati & 0.052 & 1.398 & 0.196 & 2.156 & 5.489 & 10.736 & 9.7 & 60.472 \\
\hline Lokwan & 0.079 & 1.982 & 0.250 & 2.413 & 5.025 & 12.371 & 10.246 & 62.002 \\
\hline
\end{tabular}


Table.5 Purity and impurity of various flours

\begin{tabular}{|c|c|c|c|c|c|c|c|c|}
\hline \multirow{2}{*}{ Variety } & \multicolumn{2}{|c|}{ Maida I } & \multicolumn{2}{c|}{ Maida Ii } & \multicolumn{2}{c|}{ Chakki Atta } & \multicolumn{2}{c|}{ Mill Atta } \\
\cline { 2 - 9 } & Impurity & Purity & Impurity & Purity & Impurity & Purity & Impurity & Purity \\
\hline Sharbati & 1.45 & 98.55 & 2.352 & 97.64 & 1.233 & 98.767 & 1.33 & 98.677 \\
\hline Lokwan & 2.061 & 97.939 & 2.663 & 97.337 & 17.396 & 65.208 & 72.248 & 27.752 \\
\hline
\end{tabular}

Table.6 Colour variations of different flours

\begin{tabular}{|c|c|c|c|c|c|c|}
\hline Variety & Maida I & Maida Ii & $\begin{array}{c}\text { Chakki } \\
\text { Atta }\end{array}$ & $\begin{array}{c}\text { Mill } \\
\text { Atta }\end{array}$ & $\begin{array}{c}\text { Semolina } \\
\text { I }\end{array}$ & Semolina Ii \\
\hline \multirow{2}{*}{ Sharbati } & $\begin{array}{c}\text { Bright } \\
\text { White }\end{array}$ & $\begin{array}{c}\text { Cream } \\
\text { White }\end{array}$ & $\begin{array}{c}\text { Golden } \\
\text { Brown }\end{array}$ & $\begin{array}{c}\text { Off } \\
\text { White }\end{array}$ & Golden Brown & Golden Brown \\
\hline \multirow{2}{*}{ Lokwan } & $\begin{array}{c}\text { Cream } \\
\text { White }\end{array}$ & $\begin{array}{c}\text { Off } \\
\text { White }\end{array}$ & $\begin{array}{c}\text { Golden } \\
\text { Brown }\end{array}$ & $\begin{array}{c}\text { Off } \\
\text { White }\end{array}$ & Golden Brown & Golden Brown \\
\hline
\end{tabular}

Table.7 Moisture content of different flours in percentage(\%)

\begin{tabular}{|c|c|c|c|c|c|c|}
\hline Variety & Maida I & Maida Ii & $\begin{array}{c}\text { Chakki } \\
\text { Atta }\end{array}$ & $\begin{array}{c}\text { Mill } \\
\text { Atta }\end{array}$ & Semolina I & Semolina Ii \\
\hline Sharbati & $13.724 \%$ & $13.129 \%$ & $11.077 \%$ & $13.66 \%$ & $13.88 \%$ & $14.38 \%$ \\
\hline Lokwan & $12.010 \%$ & $12.448 \%$ & $10.532 \%$ & $12.731 \%$ & $12.961 \%$ & $13.6599 \%$ \\
\hline
\end{tabular}

Table.8 Ash content of different flours in percentage(\%)

\begin{tabular}{|c|c|c|c|c|}
\hline Variety & Maida I & Maida Ii & Chakki Atta & Mill Atta \\
\hline Sharbati & $0.509 \%$ & $0.815 \%$ & $1.43 \%$ & $0.565 \%$ \\
\hline Lokwan & $0.791 \%$ & $0.922 \%$ & $1.669 \%$ & $0.846 \%$ \\
\hline
\end{tabular}

Table.9 Gluten content of different flours in percentage(\%) on wet basis

\begin{tabular}{|c|c|c|c|c|}
\hline Variety & Maida I & Maida Ii & Chakki Atta & Mill Atta \\
\hline Sharbati & $7.85 \%$ & $9.401 \%$ & $8.416 \%$ & $8.38 \%$ \\
\hline Lokwan & $7.141 \%$ & $8.456 \%$ & $8.016 \%$ & $8.0132 \%$ \\
\hline
\end{tabular}

Table.10 Gluten content of different flours in percentage $(\%)$ on dry basis

\begin{tabular}{|c|c|c|c|c|}
\hline Variety & Maida I & Maida Ii & Chakki Atta & Mill Atta \\
\hline Sharbati & $9.263 \%$ & $10.87 \%$ & $9.338 \%$ & $9.691 \%$ \\
\hline Lokwan & $8.300 \%$ & $8.849 \%$ & $8.208 \%$ & $8.452 \%$ \\
\hline
\end{tabular}


Table.11 Water absorption power of different flours in percentage(\%)

\begin{tabular}{|c|c|c|c|c|}
\hline Variety & Maida I & Maida Ii & Chakki Atta & Mill Atta \\
\hline Sharbati & $60 \%$ & $60.4 \%$ & $68 \%$ & $66 \%$ \\
\hline Lokwan & $60 \%$ & $60.4 \%$ & $68 \%$ & $66 \%$ \\
\hline
\end{tabular}

Table.12 Height of bread made from maida of the two varieties of wheat

\begin{tabular}{|c|c|}
\hline Variety & Height Of Bread (cm) \\
\hline Sharbati & 12 \\
\hline Lokwan & 10.2 \\
\hline
\end{tabular}

From above table we found that the gluten content of sharbati variety on wet basis obtained for maida I is $7.85 \%$, for maida II is $9.401 \%$, for chakkiatta is $8.416 \%$ and for mill atta is $8.38 \%$. The gluten content of lokwan variety on wet basis obtained for maida $\mathrm{I}$ is $7.141 \%$, for maida II is $8.456 \%$, for chakkiatta is $8.016 \%$ and for mill atta is $8.0132 \%$.

From above table we found that the gluten content for sharbati variety on dry basis obtained for maida I is $9.263 \%$, for maida II is $10.87 \%$, for chakkiatta is $9.338 \%$ and for mill atta is $9.691 \%$.The gluten content for lokwan variety on dry basis obtained for maida I is $8.300 \%$, for maida II is $8.849 \%$, for chakkiatta is $8.208 \%$ and for mill atta is $8.452 \%$.

\section{Water absorption power}

The amount of water required to make the dough for gluten is multiplied by 4 to to get the water absorption power of flour for 100 gms. It is expressed in terms of \%. Table 11 shows the water absorption power of various flours of the two varieties of wheat.

For a good quality flour minimum water absorption power for maidaI, maidaII, mill atta and chakkiatta must be minimum $60 \%$.From above table we found that the water absorption power obtained for maida I is $60 \%$, for maida II is $60.4 \%$, for chakkiatta is $68 \%$ and for mill atta is $66 \%$ which is same for both the varieties of wheat .

\section{Strength testing of flour}

The strength of flour is determined by making bread the obtained flours from the varieties of wheat. The bread is made under same conditions and the procedure is followed for making the bread is also same. Table 12 shows the results obtained from the strength testing of flours.

From above table we found that the height of bread made from sharbati variety was $12 \mathrm{~cm}$ and from lokwan variety was found to be 10.2 $\mathrm{cm}$. The rise in bread during the procedure occurs due to fermentation produces carbon dioxide bubbles, which, trapped by the gluten network. Gluten it binds water through hydration. From gluten test we already found that the gluten percentage is more in sharbati as compared to lokwan thus signifying the strength of bread. This test also done for finding the quality of flours. The more the rise in bread the more good quality flour it is said.

It can be concluded that in terms of moisture content, ash content, taste, color from the two varieties' of wheat and its flours sharbati variety wheat gives better results as compared to the lokwan variety. As for making chapati and as an healthy option lokwan variety wheat 
flour is considered more better option as the gluten content is less which is considered unhealthy for consumption and it consists fibre at higher percentage as compared to sharbati. The appearance and taste of the bakery products made from sharbati variety maida gave much appealing results as compared to the lokwan variety. The colour of the sharbatimaida was brighter which is taken into account for enhancing acceptability in the high quality bakery products as compared to the lokwan giving a dull colour. As per the study it can be stated that sharbati variety is much more better option as compared to the lokwan variety in may aspects. Both varieties shows difference in results making them acceptable in market as per the desirable further use of them which gives satisfactory products as per the demand.

\section{References}

AACC International. Approved Methods of Analysis, 11th Ed. Method 08-01.01. AshBasic method.

AACC International. Approved Methods of Analysis, 11th Ed. Method 44-15.02. MoistureAir-Oven Methods. Approved November 3, 1999.AACC International, St. Paul, MN, U.S.A.

Barnes, P.J.. (1986). The influence of wheat endosperm on flour colour grade. J. Cereal Sci., 4:143-155.

Ferrãoa, M.F., and Davanzob, C.U. (2005). Horizontal attenuated total reflection applied to simultaneous determination of ash and protein contents in commercial wheat flour. Analytica Chimica Acta, 540(2):411-415.

Husejin KERAN, Mirsad SALKIĆ (2009). The importance of determination of some physical and chemical properties of wheat and flour. Agricultural concepts, Pp. 197200.

JB Ohm, OK Chung, CW Deyoe (1998) Single kernel characteristics of wheat in relation to milling Cereal Chemistry 75(1): 156-161.

Marshall et al., (1984) Effects of grain shape and size on milling yields in wheat Australian Journal Of Agricultural Research 35(5): 619-630.

Nuttal et al., (2012) A model for predicting milling yield in wheat H.Dove, R. Culvenor (Eds), 16th Australian Agronomy Conference, Armidale, NSW, Australia

Oladunmoye, O.O., R. Akinoso and A.A. Olapade (2009) Evaluation of some physicalchemical properties of wheat. Journal of food quality 33:693-708.

Oppong David, Eric Arthur, Samuel Osei Kwadwo, Eric Badu, Patrick Sakyi (2015) International Journal of Innovative Research in Science, Engineering and Technology 4(2): 753-758.

Posner, E.S. "Wheat: The Raw Material." Wheat Flour Milling (2011), 2nd printing, AACC International, Inc., 1-46.

S.Y. Sonaye1, Dr. R. N. Baxi (2012) Particle size measurement and analysis of flour Lung 2: 3-4.

Shewry (2002) Structure and properties of gluten: an elastic protein from wheat grain Philos. Trans. R. Soc. B, 357:133-142.

Shewry (2009) Wheat J. Exp. Bot., 60: 1537-1553.

Tsogtbayar Baasandorrj, Jae-Bom Ohm, Frank Manthey, Senay Simsek (2015) Effect of kernel size and mill type on protein, milling yield Cereal Chemistry 92(1): 81-87.

Zafar Iqbal, Imran Pasha, Muhammad Abrar, Sharoon Masih and Muhammad Shakeel Hanif (2015). Physico-chemical, functional and rheological properties of wheat varieties. J. Agric. Res., 2015, 53: 2-9.

\section{How to cite this article:}

Minali Masih, Tushar V. Desale and Shivani Saini. 2020. Evaluation and Comparison between Physical and Chemical Properties of Two Variety Wheat. Int.J.Curr.Microbiol.App.Sci. 9(07): 2379-2388. doi: https://doi.org/10.20546/ijcmas.2020.907.278 